\title{
KONSEP KOMUNAL RELIGIUS SEBAGAI BAHAN UTAMA DALAM PEMBENTUKAN UUPA DAN DAMPAKNYA TERHADAP PENGUASAAN TANAH ADAT DI BALI
}

\begin{abstract}
I Made Suwitra
Fakultas Hukum Universitas Warmadewa Denpasar

Abstrak

Konsep komunal religius merupakan salah satu hasil penuangan hukum adat sebagai bahan utama dalam pembentukan UUPA, di samping asas-asas, dan lembaga hukum serta sistem pengaturan yang menjadi isi politik Hukum Tanah Nasional. Dalam hukum adat mengenai tanah, konsep komunal religius mengandung makna, bahwa tanah ulayat diyakini sebagai anugerah dari kekuatan gaib dan sebagai milik bersama. Hak milik pribadi hanya berlaku dalam pengertian hak memperoleh dan mengurus atau mengelolanya. Konsep ini kemudian diimplementasikan dalam UUPA dengan bentuk penguasaan tanah secara individual, dengan hak-hak atas tanah yang bersifat pribadi, sekaligus mengandung unsur kebersamaan (Pasal 16 jo Pasal 20, Pasal 6 UUPA). Jadi regulasinya direfleksikan untuk lebih diarahkan pada pendaftaran hak perorangan atas tanah. Dampaknya status "ayahan" yang awalnya melekat pada tanah-tanah adat yang dikuasai secara individu akan hilang karena tanah tersebut telah didaftarkan melalui konversi.
\end{abstract}

Kata Kunci: Komunal religius, ayahan, konversi

\section{Abstract}

The concept of communal religious is one of the pouring of customary law as the main ingredient in the formation of the BAL, in addition to the principles, institutions and legal and regulatory system that became the political content of the National Land Law. In the customary law of the land, the concept of communal religious meaning, that the lands believed to be the gift of supernatural powers and as belonging together. Private property is only valid in the sense of rights to obtain and administer or manage. This concept is then implemented in the BAL with the form of individual land ownership, with rights over land that is private, as well as an element of togetherness (Article 16 in conjunction with Article 20, Article 6 BAL). So regulation is reflected to be more focused on individual rights to land registration. The impact the status of "ayahan" which was originally attached to the customary lands which are held by an individual will be lost because the land has been registered through the conversion.

Keywords: Communal religious, ayahan, conversion

\section{PENDAHULUAN}

Undang-undang Nomor 5 Tahun

1960 tentang Peraturan Dasar Pokok-

Pokok Agraria yang lebih dikenal dengan UUPA dan telah disahkan pada tanggal 24 September 1960, dinyatakan sebagai tonggak yang sangat penting dalam sejarah perkembangan agraria/ pertanahan di Indonesia yaitu sebagai salah satu upaya mewujudkan unifikasi hukum dalam bidang pertanahan, walaupun unifikasi tersebut dapat dinyatakan bersifat "unik", karena masih memberikan kemungkinan berlakunya 
hukum adat dan agama. (Boedi Harsono, 2003;1)

Pengakuan hukum adat dalam UUPA dapat dicermati sejak awal, yaitu melalui Konsiderans/Berpendapat yang menyatakan, bahwa "perlu adanya hukum agraria nasional, yang berdasarkan atas hukum adat tentang tanah". Lebih lanjut dalam Pasal 5 UUPA ditemukan adanya pernyataan, bahwa "Hukum agraria yang berlaku atas bumi, air dan ruang angkasa ialah hukum adat".

Makna pernyataan istilah "berdasar atas dan ialah hukum adat" tersebut, menunjukkan adanya hubungan fungsional antara UUPA dengan Hukum Adat . Oleh karena itu dalam pembangunan Hukum Tanah Nasional (yang selanjutnya disebut HTN), maka Hukum Adat berfungsi sebagai sumber utama dalam mengambil bahan-bahan yang diperlukan. Namun demikian dalam hubungannya dengan Hukum Tanah Nasional Positif, norma-norma Hukum Adat berfungsi sebagai hukum yang melengkapi. Jadi fungsi hukum adat dalam HTN, yaitu: Pertama, sebagai sumber utama pembangunan HTN, dan kedua, sebagai sumber pelengkap hukum tanah positif di Indonesia. (Boedi Harsono, 2003; 205)

Hukum adat dinyatakan menjadi sumber utama pembangunan HTN, karena bahan utama pembangunan HTN dalam wujud: konsepsi (falsafah), asas-

asas hukum, lembaga-lembaga hukum, untuk dirumuskan menjadi normanorma hukum yang tertulis, yang disusun menurut sistem hukum adat. UUPA dapat dinyatakan sebagai hasil penuangan hukum adat dalam peraturan perundang-undangan sebagai hukum yang tertulis. (Boedi Harsono, 2003; 206). Dengan kata lain, konsepsi/falsafah, asas-asas, dan lembaga hukum serta sistem pengaturan yang menjadi isi politik HTN terutama diperoleh dari hukum adat. (Oloan Sitorus dan H.M. Zaki Sierrad, 2006; 47).

Hukum Adat sebagai pelengkap HTN, artinya jika suatu soal belum atau belum lengkap mendapat pengaturan dalam HTN, yang berlaku terhadapnya adalah ketentuan Hukum Adat, seperti diatur dalam Pasal 56, 58 UUPA (Boedi Harsono, 2003; 213).

Menurut Nurhasan Ismail, UUPA dilihat dari kandungan nilai sosialnya dikategorikan sebagai hukum prismatik, karena berhasil menjadikan nilai sosial tradisional dan modern secara bersamaan sebagai dasar menetapkan prinsipprinsipnya. (Oloan Sitorus dan H.M. Zaki Sierrad, 2006; 47). Kondisinya akan menjadi lebih baik apabila terjadi koeksistensi antara kepentingan lokal dengan kepentingan nasional.

Hubungan fungsional antara UUPA dengan hukum adat ini tampaknya relevan dengan kondisi Negara I Made Suwitra 
Indonesia yang bercorak multikultural, multi etnik, agama, ras dan multi golongan. Juga relevan dengan sesanti Bineka Tunggal Ika yang secara de facto mencerminkan kemajemukan budaya bangsa dalam naungan Negara Kesatuan Republik Indonesia. (I Nyoman Nurjaya, 2006;1) . Jadi warna pluralisme hukum tampaknya masih mendapat tempat, dibina dan dikembangkan.

Hubungan fungsional ini juga merefleksikan adanya tujuan hukum yang tidak hanya secara konvensional diarahkan untuk menjaga keteraturan dan ketertiban sosial (social order) dalam masyarakat yang fungsinya hanya menekankan sebagai instrumen pengawasan sosial (social control). Pada masyarakat yang lebih kompleks fungsi hukum kemudian dikembangkan sebagai alat untuk merekayasa kehidupan sosial (social engineering) untuk mewujudkan nilai kepastian hukum. Namun lebih dari itu fungsi hukum hendaknya dapat ditingkatkan agar dapat memainkan peran sebagai instrumen untuk memelihara dan memperkokoh integrasi bangsa dalam masyarakat yang bercorak multikultural. (I Nyoman Nurjaya, 2006; 2).

Secara filosofis pembentukan UUPA ditujukan untuk mewujudkan apa yang digariskan dalam Pasal 33 ayat (3) Undang-undang Dasar Negara Republik Indonesia Tahun 1945, bahwa "bumi, air dan kekayaan alam yang terkandung di dalamnya dikuasai oleh Negara dan dipergunakan untuk sebesar-besarnya kemakmuran rakyat."

Pernyataan ini mengandung arti bahwa menjadi kewajiban agar bumi, air, dan ruang angkasa dan kekayaan alam yang diletakkan dalam kekuasaan negara untuk mewujudkan kesejahteraan seluruh rakyat Indonesia. Kesejahteraan yang dimaksudkan adalah kesejahteraan lahir batin, adil dan merata bagi seluruh rakyat Indonesia. (H. Mohammad Hatta. 2005;1).

Mengacu pada pemikiran tersebut di atas, selayaknya dalam implementasi UUPA tidak mesti ditemukan adanya kontradiksi atau upaya marginalisasi hukum adat, karena antara UUPA dengan hukum adat akan berfungsi saling melengkapi (inter complementer) dan Saling menguntungkan (Simbiosis Mutualisme) dalam upaya mengisi kekosongan hukum yang ada. Di samping itu selayaknya pula dapat memberi rasa keadilan akan eksistensi terhadap hak ulayat sebagai hak masyarakat hukum adat setempat.

Mencermati uraian tersebut di atas, akan dikaji bagaimana konsep komunal religius dalam penguasaan dan pemilikan tanah adat dan implementasinya dalam UUPA dengan dampak ikutannya. 
Makna Konsep Komunal Religius dalam Penguasaan Tanah Adat

Falsafah yang mendasari hukum adat mengenai tanah adalah konseptual komunalistik religius, artinya hubungan antara manusia pribadi dengan masyarakat selalu mengatasnamakan atau mendahulukan kepentingan masyarakat. (Oloan Sitorus. 2004;21). Manusia dalam hukum adat terutama ialah sebagai anggota masyarakat. (R. Supomo. 1983;10), yang primer bukanlah individu, melainkan masya-rakat. Oleh karena itu hukum adat memandang kehidupan individu sebagai kehidupan yang terutama diperuntukkan buat mengabdi kepada masyarakat.

Tanah adat sebagai hak kepunyaan bersama dari suatu masyarakat hukum adat dipandang sebagai tanah bersama yang merupakan "pemberian/anugerah" dari suatu kekuatan gaib, sehingga semua hak perorangan bersumber dari tanah bersama tersebut. Oleh karenanya masyarakat akan mengembangkan sejumlah norma-norma tertentu tentang tanah baik yang dikuasai secara komunal mau pun secara perorangan. Adalah relevan dengan pernyataan IB. Lasem dalam hubungan dengan penguasaan ini, bahwa tanah-tanah adat seperti $\mathrm{Pe}$ karangan Desa (PKD), Ayahan Desa (AYDS) yang dikuasai secara individu di dalamnya terkandung konsep Tri Hita Karana, yaitu berupa Parhyangan yang berwujud Merajan (believe system), Pelemahan yang berwujud wilayah perumahan (artefact system), dan Pawongan yang berwujud anggota keluarga yang tinggal di situ (social system) yang notabene sebagai krama banjar dan krama desa adat. Semuanya ini sudah barang tentu diatur dalam awig-awig/(I Made Suwitra, 2009;152). Jadi penguasaan tanah adat ini secara ekonomis tidak hanya dimanfaatkan untuk meningkatkan kesejahteraan secara pribadi pemegangnya, tapi juga diabdikan untuk kepentingan bersama dalam bentuk pelaksanaan kewajiban berupa "ayahan" yang mempunyai dimensi sosial dan religius (Desa adat dengan Parhyangan, seperti pura Kahyangan Tiga).

Herman Soesang Obeng menyebutkan, bahwa pemilikan secara individual timbul apabila syarat de facto berupa bertempat tinggal dalam masyarakat hukum, mengerjakan tanah secara terus menerus, dan syarat de jure berupa pengakuan masyarakat akan pemilikan tersebut, berlaku secara bersamaan dalam diri pribadi yang bersangkutan. (Herman Soesang Obeng . 1975; 51)

Tanah-tanah adat sebagai tanah ulayat di Bali merupakan tanah bersama yang dikuasai dan dimiliki oleh desa adat secara komunal. Sebagian tanah komunal ini penguasaannya diserahkan 
(di-derivatif) kepada krama (warga) secara individual yang disebut sebagai hak milik tidak penuh seperti PKD, AYDS. Menurut Grotius, bahwa milik pribadi dikonsepsikan mempunyai hak untuk memiliki dan menggunakan secara pribadi. Jadi ada milik bersama tetapi dapat digunakan untuk kepentingan pribadi. (A. Sonny Keraf. 2001;59).

Beberapa sifat yang menonjol tentang pemilikan secara individu menurut hukum adat antara lain: (1)Pemilikan tanah hanya dapat dipunyai oleh warga masyarakat hukum saja; (2)Pemilikan tidak lahir berdasarkan keputusan atau izin kepala adat. Keputusan atau izin kepala adat hanya berfungsi sebagai pembuka jalan ke arah kemungkinan menguasai tanah dengan hak milik. Pemilikan lahir berdasarkan pengakuan masyarakat yang disebabkan oleh kenyataan erat tidaknya hubungan seseorang atas tanah. Erat dalam arti tanah senantiasa dikerjakan, dirawat dengan baik dan tidak diabaikan; (3)Pemilikan hanya timbul apabila syarat de facto berupa bertempat tinggal dalam masyarakat hukum, mengerjakan tanah secara terus menerus, dan syarat $d e$ jure berupa pengakuan masyarakat akan pemilikan tersebut, berlaku secara bersamaan dalam diri pribadi yang bersangkutan; (4)Berakhirnya hak milik atas tanah, berarti berhentinya pengakuan masyarakat atas hak orang yang bersangkutan (Herman Soesang Obeng, 1975;52).

Memahami hubungan penguasaan tanah dalam desa tradisional, konseptual "beschikkingrecht" dari van Vollenhoven sangat membantu. Dua unsur utama yang memberikan ciri khas hak ini yakni, pertama: tiadanya kekuasaan untuk memindahkan tanah, dan kedua, terdapat interaksi antara hak komunal dan hak individu yang mempunyai akibat atau berlaku ke dalam maupun berlaku ke luar (R. Van Dijk. 1971;43).

Berakibat atau berlaku ke dalam artinya pertama, persekutuan dan anggota-anggotanya dapat menarik keuntungan dari tanah dan segala yang tumbuh serta hidup di atas tanah itu seperti: mengolah tanah itu, mendirikan tempat tinggal, menggembala ternak, mengumpulkan bahan makanan, berburu, memancing. Jadi hak ini hanya sebatas dipergunakan untuk memperoleh keperluan hidup keluarga dan dirinya sendiri, dan bukan untuk membentuk persediaan keperluan perdagangan (bisnis). Kedua, hak-hak perorangan itu tetap tunduk kepada hak masyarakat (hak ulayat) atas tanah ulayat tersebut, karena masih tetap ada campur tangan persekutuan (masyarakat hukum adat dalam konsep penulis) terhadap pemakaian dan pemindahan hak-hak perorangan itu. Ketiga, Persekutuan 
dapat menetapkan atau menyediakan tanah itu untuk keperluan umum, seperti untuk kuburan (setra), sekolah, tempat ibadah (pura), pasar, tanah jabatan (bengkok), di Bali dikenal dengan istilah tanah bukti/catu.

Berakibat atau berlaku ke luar artinya ada larangan bagi orang luar persekutuan untuk menarik keuntungan dari tanah ulayat, kecuali ada izin dan sudah membayar uang pengakuan (recognitie). Ketentuan ini berlaku bagi anggota persekutuan jika ia dalam menarik keuntungan terhadap tanah ulayat itu digunakan untuk keperluan dagang (bisnis). Kedua, larangan, pembatasan atau berbagai peraturan yang mengikat terhadap orang-orang untuk mendapatkan hak perorangan atas tanah pertanian. Artinya orang luar jika akan mengolah tanah persekutuan hanya diberikan hak menikmati (genotrecht) dalam satu kali panen, mereka tidak boleh menjadi ahli waris, atau membeli tanah. Jadi hanya memperoleh kesempatan untuk turut serta menggunakan tanah wilayah persekutuan.

Setiap orang yang diperbolehkan membuka tanah liar (kosong), membuka hutan, ia diperbolehkan mempunyai hak milik atas tanah (erfelijk individueel bezitsrecht), terutama untuk daerah Jawa Timur, Jawa Tengah, dan Jawa Barat (Achmad Sodiki, 1994; 20). Tanah yang dimiliki tersebut dapat dipindah

Konsep Komunal Religius Sebagai Bahan Utama Dalam Pembentukan UUPA Dan Dampaknya Terhadap Penguasaan Tanah Adat Di Bali tangankan seperti dijual, diwariskan, digadaikan (R. Roestandi Ardiwilaga dalam Aslan Noor. 2006;65).

Yurisprudensi Mahkamah Agung (MA) tanggal 7 Februari 1959 No.59K/Sip/1958 menentukan bahwa menurut hukum adat Karo sebidang tanah "kesain" yaitu sebidang tanah kosong, yang letaknya dalam kampung, bisa menjadi hak milik perorangan setelah tanah itu diusahakan secara intensif oleh seorang penduduk kampung itu (Chidir Ali, 1979;22).

Perolehan hak secara tradisional ini adalah relevan dengan teori "accupatio" terhadap cara perolehan hak milik, artinya pendudukan tanah yang tergolong "res nullius", yaitu tanah yang belum dimiliki oleh seseorang. Apa yang telah ditemukan oleh seseorang menjadi milik orang yang bersangkutan. Cara perolehan hak milik seperti ini juga sesuai dengan Teori Hukum kodrat seperti yang dinyatakan oleh Hugo Grotius yakni: Semua benda pada mulanya adalah res nullius (benda-benda yang tidak ada pemiliknya). Tetapi masyarakat membagi-bagi semua benda dengan dasar persetujuan. Benda-benda yang tidak dibagi secara demikian, selanjutnya ditemukan oleh perorangan dan dijadikan kepunyaan masingmasing. Dengan demikian benda tersebut tunduk pada penguasaan individual. Satu kekuasaan penuh untuk I Made Suwitra 
menentukan penggunaan benda (power

of disposition) adalah dideduksikannya dari penguasaan individual itu, sebagai suatu yang terkandung di dalamnya menurut logika dan kekuasaan bersama ini menjadi dasar untuk memperolehnya dari orang lain. Yang tuntutan haknya berdiri langsung atau tidak langsung di atas landasan alamiah dari pembagian asli baik oleh persetujuan, penemuan, atau pendudukan sesudahnya (Aslan Noor, 2006;48).

Di Bali hak penguasaan tanah juga dilandasi oleh hak ulayat atau hak prabumian. Kondisi ini akan sangat relevan jika dikaitkan antara hubungan terjadinya desa adat dan tanah adat dalam perspektif sejarahnya. Di samping itu relevan juga dengan teori hukum alam dan accupatio dalam arti adanya penguasaan dan pemilikan bersama (komunal) dan juga penguasaan dan pemilikan secara individual (perseorangan). Hubungan antara hak komunal dengan hak individual juga nampak saling mendesak, menebal dan menipis, mulur-mungkret. Bahkan lebih didominasi oleh hak individual, terutama dalam pemanfaatan tanah pekarangan beserta telajakannya (I Made Suwitra, 2005;15). Proses menebal dan menipisnya hubungan hak komunal dengan hak individu itu nampaknya sangat bergantung pada kepekaan prajuru adatnya dan kesadaran krama desa terhadap tanah-tanah adat yang dikuasainya dalam menentukan apakah hak milik komunal akan berubah statusnya menjadi hak milik individu penuh. Tanah yang dulunya termasuk tanah adat ada kalanya sudah dialihkan menjadi hak milik pribadi penuh yang lebih dikenal dengan tanah Sertifikat Hak Milik (SHM), seperti tanah AYDS yang ada di Desa Adat Kemenuh Gianyar setelah kemerdekaan beralih menjadi tanah individu penuh, sebagai akibat dikeluarkannya surat pajak oleh pemerintah, padahal awalnya AYDS merupakan satu kesatuan dengan tanah PKD.

Desa adat dalam hal ini tampaknya belum memahami implikasi adanya konversi dari AYDS menjadi tanah individu penuh, dan saat ini baru sadar, karena AYDS pada dasarnya nutug (mengekor) pada PKD, artinya segala keperluan bahan upakara dan upacara keagamaan biasanya berasal dan dihasilkan dari tanah AYDS yang disebut teba atau juga sebagai sumber bahan kebutuhan pokok jika tanah AYDS berupa tanah sawah. Bahkan tempat kegiatan yang berhubungan dengan aktivitas adat dapat dilakukan di teba (AYDS) sebagai nista mandala (teben) sesuai dengan konsep Tri Mandala, yaitu tiga stratifikasi fungsi kawasan yang terdiri dari utama mandala (kawasan suci), madya mandala sebagai kawasan untuk tempat hidupnya dan kehidupan I Made Suwitra 
krama desa, dan nista mandala sebagai kawasan tidak suci, seperti penguburan, ngaben yang biasanya terletak di ilir (teben) desa (Afirmasi dengan IB. Lasem tanggal 7 Agustus 2008). Tanah-tanah adat ini disebutkan sebagai "druwe" atau "druwen" desa (adat), berarti gelah (Bali) atau kepunyaan, milik, kekuasaan desa adat (IW. Simpen, 1985: 60). Jadi tanah-tanah yang ada dalam wilayah (wewengkon) desa adat merupakan druwe (n) desa, kecuali tanah pribadi penuh. Jadi dari konsep druwe ini, tanahtanah adat sebagai tanah ulayat ada dalam kekuasaan desa adat, konsekuensinya muncul wewenang untuk mengurus dalam arti memelihara dan memimpin peruntukannya, juga yang secara langsung memanfaatkan untuk kepentingan umum, seperti untuk setra, pasar desa, balai desa.

Penguatan hubungan antara desa adat dengan tanahnya itu, kemudian dibuatkan aturan yang kemudian disuratkan dalam awig-awig yang melarang adanya pengalihan hak atau jual beli tanah kepada orang yang bukan sebagai krama desa setempat, juga dilarang untuk mengagunkan tanah dimaksud, kecuali dipergunakan sesuai dengan tujuan (petitis) seperti yang tercantum dalam awig-awig dan memperoleh persetujuan melalui paruman desa. Salah satu awig desa adat seperti dalam Pawos 28 Awig-awig Desa Adat Ngis ditegaskan: Tan kalugra ngadol miwah ngantahan sekancan padruwen desa, sejawaning kagunayang manut petitis tur polih pemutus sejeroning perarem desa (dilarang menjual atau mengagunkan semua milik desa, kecuali digunakan sesuai dengan tujuan yang ada dalam awig dan telah mendapat persetujuan melalui paruman desa).

Hubungan yang erat antara desa adat dengan tanah adatnya yang bersifat religio magis ini nampak sekali sejak awal, yaitu sebelum dilakukan perabasan hutan pada saat kedatangan Maha Yogi Markandya yang ke dua, diadakan upacara keagamaan Bhuta Yadnya dengan menanam pancadatu di kaki Gunung Agung yang sekarang dikenal dengan Pura Basukian di Besakih, adanya tempat suci yang sekarang dikenal dengan Kahyangan Tiga sebagai unsur esensial di setiap desa adat. Adanya tempat suci yang disebut sanggah atau merajan pada setiap pekarangan rumah krama desa. Di setiap setra juga ada tempat sucinya yang disebut Pura Prajapati. Sedangkan di setiap pasar ada Pura Melanting.

Secara umum hak penguasaan atas tanah atau yang juga disebut hak atas tanah adalah hubungan hukum yang memberi wewenang untuk berbuat 
sesuatu atas tanah itu. Hak penguasaan atas tanah ini dapat dipakai dalam arti fisik dan yuridis. Pengertian penguasaan dan menguasai di sini dapat berdimensi perdata dan publik, namun pemilahan secara tegas tidak dikenal dalam hukum adat. Penguasaan dalam dimensi perdata adalah penguasaan yang memberi "wewenang untuk mempergunakan" tanah yang bersangkutan, sedangkan penguasaan dalam dimensi publik, memberi "wewenang kepada pemegangnya (desa adat) untuk mengurus dan mengatur" tanah (wilayah) yang dikuasainya (K. Oka Setiawan, 2003;105).

Menurut konsepsi di atas, maka yang dimaksudkan dengan hak penguasaan atas tanah adalah adanya hubungan hukum antara pemegang hak dan tanahnya. Hak itu memberikan kekuasaan atau wewenang kepada pemegangnya untuk memperoleh hasil dari tanah yang dikuasai itu dengan memperhatikan aturan hukumnya. Oleh karena itu dianggap perlu memahami terhadap siapa subjek atau pemegang hak atas tanah yang bersangkutan dan apakah nama objek atau tanah yang dipegang tersebut (K. Oka Setiawan, 2003;105). Dari konsep si atas, dapat dinyatakan, bahwa hak penguasaan atas tanah oleh desa adat di Bali dapat dikelompokkan menjadi dua kelompok utama, yaitu: Hak milik individu dan hak milik komunal. Secara rinci menurut pengamatan penulis, dapat digambarkan dalam bagan sebagai berikut:

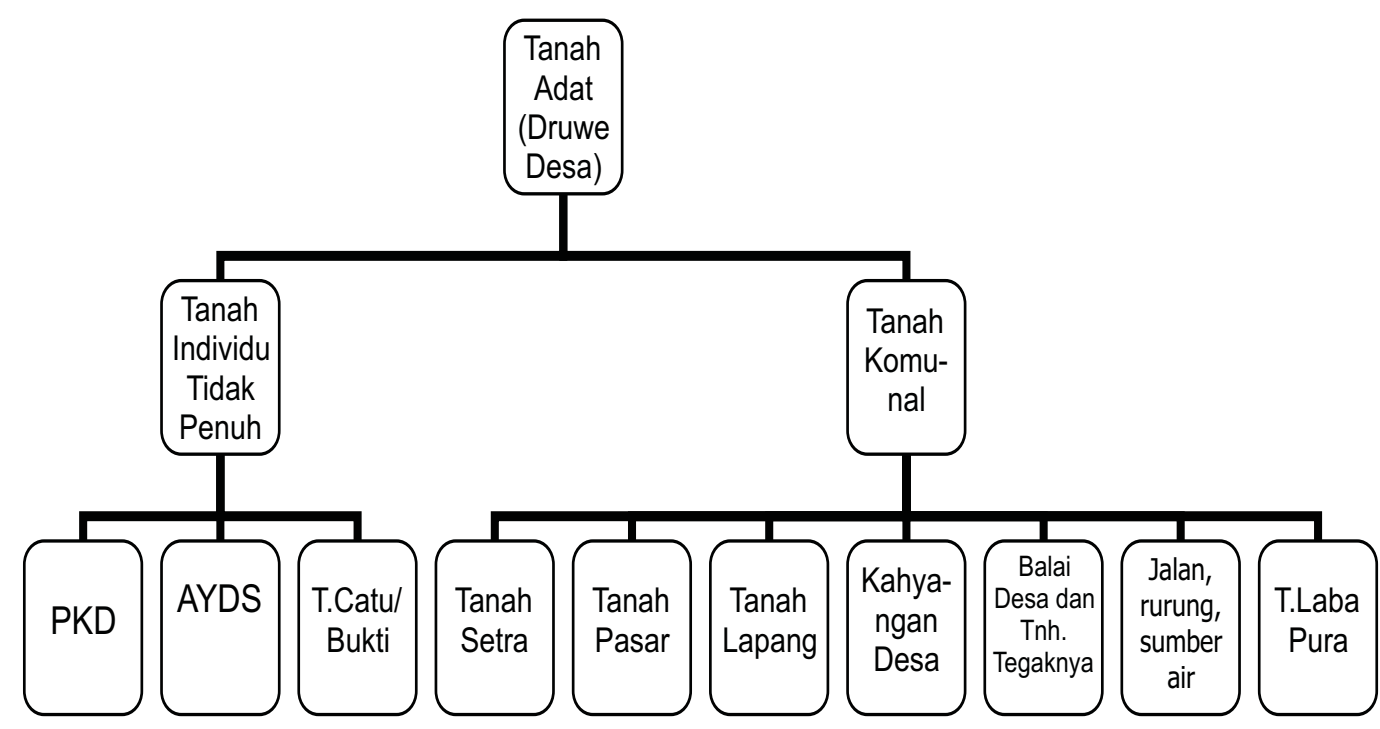


Dari bagan di atas, dapat dicermati bahwa konsep komunal religius dalam penguasaan dan pemilikan tanah adat ada dalam ikatan kemasyarakatan dalam bentuk "ayahan" yang mempunyai dimensi sosial dan religius, artinya pemegang tanah adat diikat oleh kewajiban untuk mengabdi kepada banjar dan desa adatnya di satu sisi, sedangkan di sisi lain wajib berbakti kepada Tuhan Yang Maha Esa melalui ayahan ke pura.

\section{Dampak Ketentuan Konversi dalam UUPA terhadap Hak Penguasaan dan Pemilikan Tanah Adat}

Ketentuan konversi dalam UUPA (Undang-undang Nomor 5 Tahun 1960 diatur dalam beberapa pasal, yaitu antara lain:

Pasal I (1)Hak eigendom atas tanah yang ada mulai berlakunya Undang-undang ini sejak saat tersebut menjadi hak milik, kecuali jika yang mempunyai tidak memenuhi syarat sebagai yang tersebut dalam Pasal 21; (2)Hak eigendom kepunyaan Pemerintah Negara Asing, yang dipergunakan untuk kepentingan rumah kediaman kepada perwakilan dan gedung kedutaan, sejak mulai berlakunya Undangundang ini menjadi hak pakai tersebut dalam Pasal 41 Ayat (1) yang akan berlangsung selama tanahnya dipergunakan untuk keperluan tersebut di atas; (3)Hak eigendom kepunyaan orang asing, seorang warga negara di samping kewarganegaraan Indonesia-nya mempunyai kewarganegaraan asing dan badan-badan hukum, yang tidak ditunjuk oleh pemerintah sebagai dimaksud dalam Pasal 21 ayat (2) sejak mulai berlakunya Undang-undang ini menjadi hak guna bangunan tersebut dalam Pasal 35 ayat (1) dengan jangka waktu 20 tahun; (4) Jika hak eigendom tersebut dalam ayat (1) Pasal ini dibebani dengan hak-hak erfpacht, maka hak opstaal dan hak erfpacht itu sejak mulai berlakunya Undang-undang ini menjadi hak guna bangunan dalam Pasal 35 ayat (1), yang membebani hak milik yang bersangkutan selama sisa waktu hak opstaal atau hak erfpacht tersebut di atas, tetapi selamanya 20 Tahun; (5) Jika hak eigendom tersebut dalam ayat (3) pasal ini dibebani dengan hak opstaal atau hak erfpacht, maka hubungan antara yang mempunyai hak eigendom tersebut dan pemegang hak opstaal atau hak erfpacht selanjutnya diselesaikan menurut pedoman yang ditetapkan oleh Menteri Agraria. (6) Hak-hak hypotheek, servituut, vruchtgebruik dan hak-hak lain yang membebani hak eigendom tetap membebani hak milik dan hak guna bangunan tersebut dalam ayat (!) dan (3) pasal ini, sedang hak-hak tersebut menjadi suatu hak menurut Undangundang ini.

Pasal II (1) hak-hak atas tanah 
yang memberi wewenang sebagaimana atau mirip dengan hak yang dimaksud dalam Pasal 20 ayat (1) seperti yang disebut dengan nama sebagai di bawah, yang pada mulai berlakunya Undangundang ini, yaitu: hak agrarisch eigendom, milik, andarbeni,yasan, hak atas druwe, Hak atas druwe desa, jeseni, grant Sultan, landerijenbezitrecht, altijddurende erfpacht, hak usaha atas bekas tanah partikelir dan hak-hak lain dengan nama apapun juga yang akan ditegaskan lebih lanjut oleh Menteri Agraria, sejak mulai berlakunya Undang-undang ini menjadi hak milik tersebut dalam Pasal 20 ayat (1), kecuali jika yang mempunyainya tidak memenuhi syarat sebagai yang tersebut dalam Pasal 21; (2) Hak-hak tersebut dalam ayat (1) kepunyaan orang asing, warga negara yang di samping kewarganegaraan Indonesia mempunyai kewarganegaraan asing dan badan hukum yang tidak ditunjuk oleh Pemerintah sebagai yang dimaksud dalam Pasal 21 ayat (2) menjadi hak guna usaha atau hak guna bangunan sesuai dengan peruntukan tanahnya, sebagai yang akan ditegaskan lebih lanjut oleh Menteri Agraria.

Tanah-tanah adat di Bali sesuai dengan ketentuan konversi dari UUPA tercantum dalam Pasal II seperti tersebut di atas yang disebut dengan tanah hak atas druwe atau tanah hak atas druwe desa. Tanah-tanah adat ini lebih dikenal dengan nama tanah-tanah ayah atau tanah druwe desa. Tanah druwe desa ini seperti telah disebutkan di atas, terdiri dari tanah setra, tanah pasar, tanah laba pura, tanah PKD, tanah AYDS, sumber air(kelebutan toya), loloan.

Dari tanah adat ini, nampak ada tiga subjek hak yang dapat melakukan permohonan konversi menjadi tanah hak milik, yaitu: desa adat, pura, krama (anggota) desa adat. Jika Tanah-tanah adat berupa PKD dan AYDS semuanya dikonversi menjadi hak milik (pribadi penuh), lama kelamaan akan dapat mengaburkan sifat ayahan yang melekat pada tanah adat itu. Secara normatif eks pemegang tanah adat dimaksud, tidak lagi dibebani kewajiban (ayahan) dan sifat komunal religius dari tanah tersebut juga akan hilang. Awig-awig desa adat tidak lagi mempunyai kewenangan untuk mengaturnya. Pada gilirannya eks tanah-tanah adat ini dapat dialihkan kepada orang "asing" (bukan krama desa) di luar pengawasan kepala adat (prajuru adat). Bila Ini terjadi berarti bertentangan dengan hukum agama masyarakat hukum adat yang berangkutan seperti yang diatur dalam Pasal 5 UUPA, karena eks tanah adat dapat saja dimiliki oleh orang-orang yang tidak mampu melakukan ayahan ke desa adat karena terkait dengan Kahyangan Tiga 
dan pura lainnya terutama ayahan tenaga. Kecuali jika semua ayahan fisik itu dapat diganti dengan " $u a n g$ ". Kondisi ini akan semakin parah jika semua pemegang atau pemilik tanah-tanah eks tanah adat (PKD dan AYDS) membayar ayahan ke desa atau ke pura desa.

Konversi tanah AYDS atau PKD di beberapa desa adat tampaknya disambut baik oleh masyarakat hukum adat, terutama oleh pihak yang kebetulan menguasai tanah adat dimaksud dengan berbagai latar belakang, seperti yang terjadi di Desa Adat Tamanbali Bangli melalui Proyek Operasi Nasional Agraria (PRONA) Provinsi Bali Tahun 1985/1986 telah dilakukan konversi tanah-tanah adat berupa PKD dan AYDS, yaitu yang dapat dilihat melalui tabel di bawah ini:

TABEL KONVERSI DI DESA TAMANBALI BANGLI 1985/1986

\begin{tabular}{|c|c|c|c|c|c|}
\hline No & Pemohon & $\begin{array}{l}\text { Letak/Suba } \\
\mathrm{k}\end{array}$ & $\begin{array}{l}\text { No.Pipil, } \\
\text { Persil, kls }\end{array}$ & Jenis Tanah & Luas (m2) \\
\hline 1 & I W. Surata & Sidawa & $124,112, \mathrm{II}$ & AYDS & 2600 \\
\hline 2 & I Dyarna & $\begin{array}{l}\text { Ds. } \\
\text { Tamanbali } \\
\text { No.56 a }\end{array}$ & $81,2 b$, III & $\begin{array}{l}\text { AYDS } \\
\text { Pertanian }\end{array}$ & 1400 \\
\hline 3 & $\begin{array}{l}\text { Ni Nym Kedek } \\
\text { I Ngh Sudi } \\
\text { I Kt Deri }\end{array}$ & $\begin{array}{l}\text { Ds. } \\
\text { Tamanbali } \\
\text { No.56 a }\end{array}$ & $214,26 a, I$ & $\begin{array}{l}\text { AYDS } \\
\text { Pertanian }\end{array}$ & 350 \\
\hline No & Pemohon & $\begin{array}{l}\text { Letak/Suba } \\
\mathrm{k}\end{array}$ & $\begin{array}{l}\text { No.Pipil, } \\
\text { Persil, kls }\end{array}$ & Jenis Tanah & Luas (m2) \\
\hline 4 & $\begin{array}{l}\text { Ni Nym Kedek } \\
\text { I Ngh Sudi } \\
\text { I Kt Deri }\end{array}$ & $\begin{array}{l}\text { Ds. } \\
\text { Tamanbali } \\
\text { No.56 a }\end{array}$ & $\begin{array}{l}213,26 b, \\
\text { III }\end{array}$ & $\begin{array}{l}\text { AYDS } \\
\text { Pertanian }\end{array}$ & 100 \\
\hline 5 & $\begin{array}{l}\text { Ni Nym Kedek } \\
\text { I Ngh Sudi } \\
\text { I K Deri }\end{array}$ & $\begin{array}{l}\text { Ds. } \\
\text { Tamanbali } \\
\text { No.56 a }\end{array}$ & $314,138, \mathrm{I}$ & $\begin{array}{l}\text { PKD } \\
\text { Perumahan }\end{array}$ & 600 \\
\hline 6 & I Ngh Radia & $\begin{array}{l}\text { Ds. } \\
\text { Tamanbali } \\
\text { No.56 a }\end{array}$ & $74,134, \mathrm{I}$ & $\begin{array}{l}\text { PKD } \\
\text { Perumahan }\end{array}$ & 850 \\
\hline 7 & Ni W Rabed & $\begin{array}{l}\text { Ds. } \\
\text { Tamanbali } \\
\text { No.56 a }\end{array}$ & $355,135, \mathrm{I}$ & $\begin{array}{l}\text { PKD } \\
\text { Perumahan }\end{array}$ & 850 \\
\hline 8 & I W Saju & $\begin{array}{l}\text { Br. Kawan } \\
\text { Kel. } \\
\text { Kawan } \\
\text { Bangli. }\end{array}$ & $89,24, I$ & $\begin{array}{l}\text { AYDS } \\
\text { Pertanian }\end{array}$ & 5200 \\
\hline
\end{tabular}




\begin{tabular}{|c|c|c|c|c|c|}
\hline 9 & $\begin{array}{l}\text { I W Purna } \\
\text { I Ngh Merta } \\
\text { I W Partama }\end{array}$ & $\begin{array}{l}\text { Br. SIladan } \\
\text { Tamanbali } \\
\text { 56a Sidawa } \\
\text { Bangli }\end{array}$ & $450,25, \mathrm{I}$ & $\begin{array}{l}\text { AYDS } \\
\text { Pertanian }\end{array}$ & 700 \\
\hline 10 & $\begin{array}{l}\text { I Ngh Dunia } \\
\text { I Nym Kereg }\end{array}$ & $\begin{array}{l}\text { Br. Siladan } \\
\text { Ds } \\
\text { Tamanbali } \\
\text { 56a Bangli }\end{array}$ & $185,129, \mathrm{I}$ & $\begin{array}{l}\text { PKD } \\
\text { Perumahan }\end{array}$ & 1400 \\
\hline 11 & I Nym Kerta & $\begin{array}{l}\text { Br. Siladan } \\
\text { Ds } \\
\text { Tamanbali } \\
\text { 56a Bangli }\end{array}$ & $588,130, \mathrm{I}$ & Pertanian & 300 \\
\hline 12 & I Nym Kerta & $\begin{array}{l}\text { Br. Siladan } \\
\text { Ds } \\
\text { Tamanbali } \\
\text { 56a Bangli }\end{array}$ & $588,130, \mathrm{I}$ & Pertanian & 800 \\
\hline 13 & I K Bigbig & $\begin{array}{l}\text { Br. Siladan } \\
\text { Ds } \\
\text { Tamanbali } \\
\text { 56a Bangli }\end{array}$ & $445,23, \mathrm{I}$ & $\begin{array}{l}\text { AYDS } \\
\text { Pertanian }\end{array}$ & 700 \\
\hline 14 & I K Bigbig & $\begin{array}{l}\text { Br. Siladan } \\
\text { Ds } \\
\text { Tamanbali } \\
\text { 56a Bangli }\end{array}$ & $68,132, \mathrm{I}$ & $\begin{array}{l}\text { PKD } \\
\text { Perumahan }\end{array}$ & 850 \\
\hline 15 & Got M Kaler & $\begin{array}{l}\text { Br. Pande } \\
\text { Sidawa } \\
\text { Tamanbali } \\
\text { 56a Bangli }\end{array}$ & $602,109 . \mathrm{I}$ & $\begin{array}{l}\text { PKD } \\
\text { Perumahan }\end{array}$ & 900 \\
\hline 16 & I Koci & $\begin{array}{l}\text { Br. Pande } \\
\text { Sidawa } \\
\text { Tamanbali } \\
\text { 56a Bangli }\end{array}$ & 191,113, II & $\begin{array}{l}\text { PKD } \\
\text { Perumahan }\end{array}$ & 900 \\
\hline 17 & I W Regeg & $\begin{array}{l}\text { Br. Pande } \\
\text { Sidawa } \\
\text { Tamanbali } \\
\text { 56a Bangli }\end{array}$ & 168,50, II & $\begin{array}{l}\text { AYDS } \\
\text { Pertanian }\end{array}$ & 2900 \\
\hline 18 & I W Regeg & $\begin{array}{l}\text { Br. Pande } \\
\text { Sidawa } \\
\text { Tamanbali } \\
\text { 56a Bangli }\end{array}$ & $160,133, \mathrm{II}$ & $\begin{array}{l}\text { PKD } \\
\text { Perumahan }\end{array}$ & 400 \\
\hline 19 & I W Kebet & $\begin{array}{l}\text { Br. Pande } \\
\text { Sidawa } \\
\text { Tamanbali } \\
\text { 56a Bangli }\end{array}$ & $605,106, \mathrm{II}$ & $\begin{array}{l}\text { PKD } \\
\text { Perumahan }\end{array}$ & 700 \\
\hline
\end{tabular}




\begin{tabular}{|l|l|l|l|l|l|}
\hline 20 & DW GD Tantera & $\begin{array}{l}\text { Br. Dadia } \\
\text { Ds } \\
\text { Tamanbali } \\
\text { 56a Bangli }\end{array}$ & 480,106, II & $\begin{array}{l}\text { PKD } \\
\text { Perumahan }\end{array}$ & 700 \\
\hline 21 & Pande Yatna & $\begin{array}{l}\text { Br. Pande } \\
\text { Ds } \\
\text { Tamanbali } \\
56 a \text { Bangli }\end{array}$ & 136,128, I & $\begin{array}{l}\text { AYDS } \\
\text { Pertanian }\end{array}$ & 2200 \\
\hline 22 & I Nurasta & $\begin{array}{l}\text { Br. Gaga } \\
\text { Ds } \\
\text { Tamanbali } \\
56 a \text { Bangli }\end{array}$ & 478, I & $\begin{array}{l}\text { PKD } \\
\text { Perumahan }\end{array}$ & 950 \\
\hline
\end{tabular}

Sumber: Lampiran pengumuman pertama persertifikatan hak atas tanah pada Proyek Operasi Nasional (PRONA) Agraria Provinsi Bali Tahun 1985/1986.

Di desa adat lain di Bali, konversi tanah-tanah adat ini juga tidak dapat dihindarkan, seperti yang terjadi di Desa Adat Kemenuh Gianyar. Hampir semua tanah AYDS telah dikonversi sebagai akibat telah dikeluarkan surat pajak sejak masa pemerintahan Hindia Belanda, sehingga saat ini tanah AYDS sulit dijumpai. Sedangkan tanah PKD masih ada (I Made Suwitra, 2009; 208).

Di Desa Adat Ngis Karangasem, tanah-tanah AYDS hanya dikuasai oleh krama desa seket lima, yaitu krama desa yang dianggap keturunan dari para leluhur yang dianggap telah berjasa pada jaman dahulu dalam membuka hutan lebat (nges) menjadi desa (Ngis) seperti sekarang. Tanah AYDS ini pun sebagian besar sudah disertifikatkan menjadi hak milik atas nama krama (warga) yang secara riil menguasai tanah dimaksud, yaitu kurang lebih tahun 1982, yaitu saat ada Proyek Rehabilitasi Perkebunan Tanaman Eksport (PRPTE) dari Dinas Perkebunan untuk memberikan bantuan kredit dalam bentuk pupuk dan sarana produksi pertanian (Saprotan) termasuk bantuan untuk mensertifikatkan tanahtanah AYDS yang sudah dikuasainya sejak dahulu. Sertifikatnya kemudian dijadikan agunan di BRI atas kredit yang diberikan itu (I Made Suwitra, 2009; 208). Walaupun telah disertifikatkan, status ayahan masih melekatinya, konsekuensinya pada setiap kegiatan upacara keagamaan di desa adat, krama seket lima menjadi inti pelaksananya dari aspek tenaga, dan juga ditambah ayahan berupa bahan-bahan upacara yang sudah barang tentu lebih banyak dipikul dibandingkan dengan krama biasa yang lainnya.

Saat ini memang status ayahan pada AYDS yang sudah disertifikatkan 
masih ada, namun sejarah perjalanan waktu akan terus mengujinya, apakah status ayahannya akan dapat tetap melekatinya, apabila sudah ada pergantian generasi yang secara pasti akan terjadi, karena tanah dimaksud akan diterima lanjutkan (diwariskan) kepada generasi berikutnya yang sudah barang tentu tidak tahu asal usul tanah yang diterima tersebut.

masih ada, namun sejarah perjalanan waktu akan terus mengujinya, apakah status ayahannya akan dapat tetap melekatinya, apabila sudah ada pergantian generasi yang secara pasti akan terjadi, karena tanah dimaksud akan diterima lanjutkan (diwariskan) kepada generasi berikutnya yang sudah barang tentu tidak tahu asal usul tanah yang diterima tersebut.

Secara riil akan tampak hak individu menjadi semakin kuat, sedangkan hak komunal (desa adat) menjadi melemah, dan bahkan hilang sama sekali. Adalah relevan dengan konsep mulur-mungkret yang dinyatakan Iman Sudiyat tentang hubungan hak-hak persekutuan dan hak-hak perorangan setiap anggotanya yang saling mempengaruhi.

Maksud dari ketentuan konversi ini memang ditujukan untuk dapat lebih menjamin nilai kepastian hukum terhadap hak atas tanah, di mana UUPA memang lebih kental mengarah pada nuansa individualisasi terhadap hak milik atas tanah. Ketentuan ini tampaknya akan kontradiktif apabila dibandingkan dengan Konsiderans/Berpendapat dan Pasal 5 dari UUPA itu sendiri yang mengakui hukum adat sebagai sumber utama dan juga sebagai pelengkap dalam pembentukan HTN.

Berbeda dengan maksud ketentuan Pasal 3 UUPA, di mana pelaksanaan hak ulayat dan hak-hak yang serupa itu dari masyarakat-masyarakat hukum adat, sepanjang menurut kenyataannya masih ada, harus sedemikian rupa. Ini mengindikasikan, bahwa negara mengakui eksistensi hak ulayat masyarakat hukum adat jika memang dalam kenyataannya masih ada, sehingga hak komunal masih diakui dengan catatan tidak bertentangan dengan kepentingan nasional dan negara. Namun apabila semua tanah adat atau tanah ayah (PKD dan AYDS) dikonversi menjadi hak milik pribadi penuh, berarti akan terjadi pembatasan berlakunya hak ulayat desa yang selanjutnya tidak mungkin untuk dihidupkan lagi.

Memang di satu sisi, UUPA berfungsi sebagai sarana merekayasa masyarakat (a tool of social engineering) yang diharapkan dapat membawa perubahan pada perilaku hukum warga 
masyarakat, yaitu terutama pada sistem pendaftaran tanah (rechtskadaster). Sarana Pembaharuan ini akan sangat tepat apabila untuk pendaftaran tanahtanah adat ini tidak dilakukan dengan melakukan perubahan terhadap subjek haknya atau tidak merubah status tanah adat dimaksud. Artinya subjek hak yang akan mendaftarkan tanah-tanah adat ini tetap dilakukan oleh desa adat. Sedangkan untuk tanah adat yang dikuasai individu (tanah pribadi tidak penuh) selayaknya status tanahnya tidak ikut berubah, apakah sebagai PKD atau AYDS atau dengan kata lain identitas tanahnya baik sebagai PKD atau AYDS tidak dihilangkan setelah diadakan konversi dan dicarikan padanannya dalam UUPA, seperti Hak Pakai (HP) untuk AYDS, dan HGB untuk PKD yang diletakkan di atas Hak Milik atau Hak Pengelolaan (HPL) desa adat sebagai masyarakat hukum adat seperti dimaksud oleh ketentuan Pasal 2 Ayat (4) UUPA, sehingga UUPA dengan hukum adat secara riil dapat saling berdampingan dalam arti dapat saling mengisi dalam hubungan fungsional. Di lain pihak untuk dapat memenuhi Fungsi sebagai sarana rekayasa atau pembaharuan dalam masyarakat (social engineering), UUPA harus mampu melindungi beberapa kepentingan, yaitu: Kepentingan umum (public interest), kepentingan masyarakat (social interest),dan kepentingan pribadi (private interest)

Fungsi hukum sebagai sarana rekayasa atau pembaharuan dari UUPA baru dapat dilaksanakan sebatas tanah laba pura, yaitu dengan ditunjuknya pura sebagai badan hukum yang dapat memiliki hak atas tanah sesuai dengan PP Nomor 38 Tahun 1963 jo Keputusan Menteri Dalam Negeri No. SK.556/DJA /1986. Oleh karena sejak Tahun 1986 persekutuan pengempon pura baru dapat mendaftarkan tanah laba puranya atas nama pura, di mana sebelumnya ada yang didaftarkan atas nama pribadi prajuru (pengurus) pura atau pribadi pemangku (petugas keagamaan yang khusus diangkat di pura yang bersangkutan).

Sebenarnya sejak dikeluarkannya UUPA masyarakat hukum adat di Bali baik secara komunal maupun secara individual berkehendak untuk dapat mendaftarkan hak atas tanahnya yang selama ini dikuasainya baik secara de facto maupun secara de jure dalam konsep hukum adat, sehingga akhirnya mendapatkan sertifikat. Kenyataan ini memang dapat dijadikan dasar permohonan hak, seperti keterangan sporadik yang dibuat oleh Kepala Desa Dinas (I Made Suwitra, 2009; 211).

Desa adat di Bali sebagai salah 
satu persekutuan hukum yang ada di wilayah negara Republik Indonesia mempunyai karakteristik yang sangat khas dibandingkan dengan persekutuan lainnya terutama dari ciri komunal religio magisnya yang sangat kental, sehingga jika dikaitkan dengan ketentuan Pasal 1 huruf c, dan d PP No. 38 Tahun 1963, yang secara limitatif menegaskan, bahwa Badan-badan hukum yang dapat mempunyai hak milik atas tanah antara lain: Badan-badan keagamaan, yang ditunjuk oleh Menteri Pertanian/Agraria setelah mendengar Menteri Agama, dan Badan-badan sosial, yang ditunjuk oleh Menteri Pertanian/Agraria setelah mendengar Menteri Kesejahteraan Sosial, maka desa adat telah memenuhi kriteria sebagai badan sosial yang religius. Namun sampai saat ini belum ditunjuk sebagai badan hukum yang dapat memiliki hak atas tanah.

Mencermati pada kondisi di atas, dapat dinyatakan bahwa dampak positif dari adanya ketentuan tentang konversi dari UUPA adalah dapat lebih menjamin adanya kepastian hukum terhadap hak penguasaan dan pemilikan tanah, sehingga juga berdampak pada adanya kepastian terhadap perlindungannya.

Di samping itu, ketentuan konversi ini juga mempunyai dampak negatif, yaitu adanya sekulerisasi dan individualisasi terhadap penguasaan dan pemilikan tanah-tanah adat yang dulunya bersifat komunal religius, juga penguasaan dan pemilikannya lebih bersifat individual sekularistik yang dulunya bercorak komunal religio magis. Oleh karena itu penguasaannya tidak lagi diikat oleh sistem "ayahan" dalam persekutuan (desa adat) tapi sudah terlepas dari akar budayanya, akhirnya dapat memunculkan sikap eksklusivisme pemiliknya terutama dalam pengasingannya, karena tidak tunduk lagi pada ketentuan hukum adat setempat (awig-awig desa adat).

Bahaya akan semakin dekat jika desa adat tidak segera sadar dan tidak cerdas menyikapinya, karena selama ini proses konversi hanya melibatkan pemerintahan desa dinas, padahal tanahtanah yang dikonversi itu merupakan tanah-tanah adat sebagai tanah ulayat yang seharusnya tunduk pada ketentuan hukum adat dan struktur pemerintahan desa adat. Proses pengumuman sebagai pelaksanaan asas publisitas dalam UUPA hanya merupakan lembar pengumuman yang dibuat oleh Kantor Pertanahan yang ditujukan kepada Kepala Desa (dinas) letak tanah dimaksud untuk ditempelkan. Namun jika mau dipahami corak hukum adat di Bali, sebenarnya pelaksanaan pengumuman ini dapat dipadukan dengan lembaga "siar" yang 
dikenal dalam hukum adat sebagi perwujudan corak terang, di mana proses "siar" dapat dilakukan dalam paruman di desa adat atau di banjar yang biasanya diadakan setiap bulan (35 hari dalam hitungan Bali), yaitu dengan mengambil bertemunya hari (sapta wara) dengan panca wara, seperti Minggu Pon. Artinya proses pengumumannya tidak hanya dilakukan di Kantor Kepala Desa (dinas) dengan cara menempelkan lembar pengumuman, juga disertai pelibatan prajuru adat untuk diajak bekerja sama (fungsi koordinatif) melakukan siar saat dilakukan paruman.

Tanah sebagai wilayah merupakan salah satu unsur esensial dari persekutuan (desa adat), sehingga apabila dilakukan konversi, hendaknya tidak sampai menghilangkan status tanah dan subjek pemegang haknya, sehingga terjadi ko-eksistensi kekuatan antara UUPA sebagai hukum nasional dengan hukum adat sebagai hukum lokal yang semestinya dapat ditampakkan, sehingga ide awal dalam penyusunan UUPA, yaitu kata "berdasar" dan "ialah" hukum adat dimaksudkan agar sifat pendaftaran dalam UUPA mampu mengadopsi filosofi adat dan taat asas (Herman Soesangobeng, 2000; 117). diberikan simpulan, konsep komunal religius yang dijadikan bahan utama dalam pembentukan UUPA dalam implementasinya memberi kemungkinan penguasaan tanah-tanah adat secara individual dengan hak-hak atas tanah yang bersifat pribadi, sekaligus mengandung unsur kebersamaan yang diberi label fungsi sosial yang berdampak pada hilangnya status "ayahan" yang sebelumnya melekati tanah adat dimaksud dan berganti dengan pemilikan yang bercorak sekuler dan individual yang disebut dengan tanah hak milik individu penuh. Oleh karena itu perlu diupayakan secara riil oleh semua pihak agar dalam mencari padanan model penguasaan dan pemilikan tanah adat tidak sampai menghilangkan status "ayahan" yang melekatinya sehingga negara di satu sisi dapat menghormati dan melindungi masyarakat hukum adat dan hak-hak tradisionalnya, dan di sisi lain tidak muncul sifat eksklusivisme dari masyarakat hukum adat (desa adat), sehingga terjadi koeksistensi antara hukum negara dan hukum adat, di mana desa adat sudah saatnya diberikan hak pengelolaan seperti yang diberikan kepada Pemerintah Daerah menurut ketentuan Pasal 2 Ayat (4) UUPA.

\section{PENUTUP}

Dari pembahasan di atas dapat 


\section{DAFTAR PUSTAKA}

Buku, Jurnal, dan Karya Ilmiah Ali, Chidir. (1979). Yurisprudensi Indonesia tentang Hukum Agraria. Binacipta. Bandung.

Ardiwilaga, R. Roestandi. Dalam Aslan Noor. (2006). Konsep Hak Milik Atas Tanah Bagi Bangsa Indonesia Ditinjau dari Ajaran Hak Asasi Manusia. CV. Mandar Maju. Bandung.

Earl Babbie. (1999). The Basics of Social Research. Wadsworth Publishing Company. Amerika. P. 260.

Boedi Harsono. (2003). Hukum Agraria Indonesia Sejarah Pembentukan UUPA Isi dan Pelaksanaannya. Jilid I Hukum Tanah Nasional, Cetakan Kesembilan (Edisi revisi). Djambatan. Jakarta.

Soesangobeng, Herman. (2000). "Pendaftaran Tanah Ulayat di Sumatera Barat dengan Contoh Pilot Proyek Pendaftaran Tanah di Desa Tiga Jangko, Kecamatan Lintau Buo, Kabupaten Tanah Datar". Dalam Himpunan Makalah dan Rumusan Workshop Tanah Ulayat di Sumatera Barat yang diselenggarakan oleh Kantor Wilayah Badan Pertanahan Nasional Propinsi Sumatra Barat pada Tanggal 23-24 Oktober 2000di Padang. H. Syofyan Jalalludin. Ed. Kepala Kantor Wilayah BPN Provinsi Sumatera Barat.

Oloan Sitorus dan H.M. Zaki Sierrad. (2006). Hukum Agraria di
Indonesia Konsep Dasar dan Implementasi. Cetakan Perdana. Mitra Kebijakan Tanah Indonesia. Yogyakarta.

Oloan Sitorus. (2004). Kapita Selekta Perbandingan Hukum Tanah, Cetakan Perdana. Mitra Kebijakan Tanah Indonesia. Yogyakarta. Hal. 21.

Nurjaya, I Nyoman. (2006). Pengelolaan Sumber Daya Alam dalam Perspektif Antropologi Hukum, Cetakan I. Kerjasama Progran Magister Ilmu Hukum Program Pascasarjana Unibraw, ARENA HUKUM Majalah Fakultas Hukum Universitas Brawijaya dengan Penerbit Universitas Negeri Malang (UM PRESS. Malang).

Hatta, H. Mohammad. (2005). Hukum Tanah Nasional dalam Perspektif Negara Kesatuan, Cetakan I. Media Abadi. Yogyakarta.

Soemitro, Ronny Hanitijo. (1983). Metodologi Penelitian Hukum. Cetakan Pertama. Ghalia Indonesia. Jakarta.

Setiawan, K Oka. (2003). "Hak Ulayat DeAdat Tenganan Pegrinsingan Bali Pasca UUPA". Cetakan I. Disertasi.sa Program Pascasarjana Fakultas Hukum Universitas Indonesia. Jakarta

Simpen, IW. (1985). Kamus Bahasa Bali. PT. Mabhakti. Denpasar

Ibrahim, Johnny. (2006). Teori \& Metodologi Penelitian Hukum Normatif. Edisi Revisi. Cetakan 
Kedua. Bayumedia Publishing, Malang Jawa Timur

Jazim Hamidi. (2005). Hermeneutika Hukum, Teori Penemuan Hukum Baru dengan Interpretasi Teks, Cetakan Pertama. UII Press. Yogyakarta

Soesang Obeng, Herman. (1975). Pertumbuhan hak milik individuil menurut hukum adat dan menurut UUPA di Jawa Timur

(2000). "Pendaftaran Tanah Ulayat di Sumatra Barat dengan contoh Pilot Proyek Pendaftaran Tanah di Desa Tiga Jongkok Kecamatan Lintau Buo Kabupaten Tanah Datar". Dalam Himpunan Makalah dan Rumusan Workshop Tanah Ulayat di Sumatra Barat. H. Sofyan Jalaluddin. Ed. Kantor Wilayah Badan Pertanhan Provinsi Sumstera Barat

Supomo, R. (1983). Hubungan Individu dan Masyarakat dalam Hukum Adat. Cetakan ke-4. Pradnya Paramita. Jakarta

Suwitra, I Made. (2009). "Eksistensi Hak Penguasaan dan Pemilikan Atas Tanah Adat di Bali dalam Perspektif Hukum Agraria Nasional". Disertasi. Program Doktor ilmu Hukum Fakultas Hukum Universitas Brawijaya. Malang

Suwitra, I Made. (2005). "Tugas Prajuru Adat dalam mengatur tanah adat khususnya tanah telajakan dalam konsep menuju Bali yang ajeg". Kertha Wicaksana. Fakultas Hukum Universitas Warmadewa.
Denpasar

\section{Peraturan Perundang-Undangan}

Ketetapan MPR RI Nomor IX/MPR /2001 tentang Pembaharuan Agraria dan Pengelolaan Sumber DayaAlam.

Undang-Undang Dasar 1945 Perubahan pertama, kedua, ketiga, dan keempat.

Burgerlijk Wetboek. 1961. Kitab Undang-undang Hukum Perdata. Terjem. R. Soebekti dan R. Tjitrosudibio. Cetakan ke empat. Pradnya Paramita. Jakarta.

Undang-Undang Nomor 5 Tahun 1960 tentang Peraturan Dasar PokokPokok Agraria.

Peraturan Pemerintah No.38 Tahun 1963 tentang Penunjukan Badan-Badan Hukum yang dapat mempunyai Hak Milik Atas Tanah.

Peraturan Pemerintah Nomor 24 Tahun 1997 tentang Pendaftaran Tanah.

Keputusan Presiden Republik Indonesia Nomor 34 Tahun 2003 tentang Kebijakan Nasional di Bidang Pertanahan.

Peraturan Menteri Negara Agraria/ Kepala Badan Pertanahan Nasional No.1/1999 tentang Tata Cara Penanganan Sengketa Pertanahan.

Peraturan Menteri Negara Agraria/ Kepala Badan Pertanahan Nasional No.3/1999 tentang Pelimpahan Kewenangan Pemberian dan 
Pembatalan Keputusan Pemberian Hak Atas Tanah Negara.

Peraturan Menteri Negara Agraria/ Kepala Badan Pertanahan Nasional No.5/1999 tentang Pedoman Penyelesaian Masalah Hak Ulayat Masyarakat Hukum Adat.

Peraturan Menteri Negara Agraria/ Kepala Badan Pertanahan Nasional No.9/1999 tentang Tata Cara Pemberian dan Pembatalan Hak Atas Tanah Negara dan Hak Pengelolaan.

Surat Keputusan menteri Dalam Negeri No. SK 556/DJA/1986 tentang Penunjukan Pura sebagai Badan Hukum Keagamaan yang dapat mempunyai Hak milik Atas Tanah.

Surat Keputusan menteri Dalam Negeri No. 61 Tahun 1979 tentang Team Surat Keputusan Kepala Badan Pertanahan Nasional No.3-V-2002 tentang Pembatalan Sertifikat.

Peraturan Daerah Propinsi Daerah Tingkat I Bali Nomor 06 Tahun 1986 tentang Kedudukan, Fungsi dan Peranan Desa Adat sebagai Kesatuan Masyarakat Hukum Adat dalam Propinsi Daerah Tingkat I Bali

Peraturan Daerah Propinsi Bali Nomor 3 Tahun 2001 Jo Nomor 3 Tahun 2003 tentang Desa Pakraman.

Peraturan Daerah Propinsi Daerah Tingkat I Bali Nomor 2 Tahun 1992 tentang Pemakaian tanah yang dikuasai oleh Pemerintah Propinsi Daerah Tingkat I Bali.
Keputusan Bupati Badung No. 637 Tahun 2003 tentang Rencana Detail Tata Ruang Kecamatan Kuta Utara.

Awig-Awig Desa Adat Ngis Kecamatan Manggis Kabupaten Karangasem. 1988. 